\title{
Hubungan Hukum Para Pihak dalam Peer to Peer Lending
}

\author{
Ratna Hartanto dan Juliyani Purnama Ramli \\ Fakultas Hukum Universitas Islam Indonesia \\ Jl. Tamansiswa No. 158 Yogyakarta \\ ratna_hartanto@yahoo.co.id; purnama_july@yahoo.com
}

Received: 15 Januari 2018; Accepted: 26 Maret 2018; Published: 5 Nopember 2018

DOI: 10.20885/iustum.vol25.iss2.art6

\begin{abstract}
The development of digital world has provided various services that are beneficial for the community, one of which is the presence of information technology-based lending and borrowing services or known as peer to peer lending. However, the current applicable regulations have not clearly explained the construction of the legal relations among the parties involved in peer to peer lending platform. Regarding the fact that some peer to peer lending services are similar to those of banks, the Financial Services Authority (OJK) is required to affirm the construction of the legal relations among parties so as to create legal certainty. Based on this explanation, there is a question: how is the Legal Relation among the Parties involved in Peer To Peer Lending in terms of the Legal Certainty for these Parties. This study used a normative method. The results showed that peer to peer lending services providers are not banks that collect funds from the community and distribute them to the community. Therefore, the legal relation among the parties involved in peer to peer lending shall be differentiated from the legal relations among the parties involved in banking sector, especially in the business activities of distributing funds through credit or financing agreements. The legal certainty in peer to peer lending shall be fulfilled so that peer to peer lending business activities are not categorized as an illegal bank and so that this business is able to provide legal standing for all the parties.
\end{abstract}

Keywords: Legal relations; parties; peer to peer lending

Abstrak

Perkembangan dunia digital telah memberikan berbagai layanan yang memudahkan bagi masyarakat salah satunya yaitu dengan kehadiran layanan pinjam meminjam uang berbasis teknologi informasi atau peer to peer lending. Namun, regulasi yang ada saat ini belum cukup jelas menggambarkan konstruksi hukum hubungan hukum antara para pihak yang terlibat dalam platform peer to peer lending tersebut. Mengingat beberapa layanan peer to peer landing menyerupai perbankan, Otoritas Jasa Keuangan perlu menegaskan konstruksi hubungan hukum para pihak agar tercipta kepastian hukum. Berangkat dari hal itu, muncul pertanyaan bagaimana hubungan hukum para pihak dalam Peer To Peer Lending (Layanan Pinjam Meminjam Uang Berbasis Teknologi Informasi) dari perspektif kepastian hukum bagi para pihak. Penelitian ini merupakan penelitian yang normatif. Hasil penelitian menunjukkan bahwa penyelenggara peer to peer lending bukanlah perbankan yang menyelenggarakan jasa penghimpunan dana dari masyarakat dan menyalurkannya ke masyarakat. Oleh karena itu, sifat hubungan hukum antara para pihak dalam peer to peer lending harus benar-benar dibedakan dengan hubungan hukum antara para pihak dalam perbankan khususnya dalam kegiatan usaha penyaluran dana melalui perjanjian kredit atau pembiayaan. Kepastian hukum dalam peer to peer lending perlu dipenuhi agar kegiatan usaha peer to peer lending tidak terkategori sebagai bank gelap dan dapat memberikan kedudukan hukum yang sah bagi para pihak.

Kata-Kata Kunci: Hubungan hukum; para pihak; peer to peer lending 


\section{Pendahuluan}

Perkembangan dunia digital telah memberikan berbagai layanan yang memudahkan bagi masyarakat salah satunya yaitu dengan kehadiran layanan pinjam meminjam uang berbasis teknologi informasi atau peer to peer lending. Melalui peer to peer lending ini, masyarakat yang memerlukan dana dalam jumlah mikro dapat secara cepat mendapatkan pinjaman tanpa perlu mengajukan kredit ke bank. Layanan pinjaman peer to peer lending dapat diakses oleh masyarakat melalui aplikasi pada gawai dua puluh empat jam nonstop. Hal ini tentu berbeda dengan fasilitas kredit atau pembiayaan perbankan dimana debitor yang memerlukan pinjaman harus mendatangi kantor perbankan terkait dan harus menjalani proses antri sampai menandatangani perjanjian kredit. Selain itu, pada layanan pinjam meminjam uang melalui peer to peer lending juga tidak mempersyaratkan adanya agunan yang tentu saja hal ini berbeda dengan fasilitas kredit ataupun pembiayaan perbankan yang biasanya mempersyaratkan adanya agunan.

Sistem peer to peer lending pertama kali dikenal di Inggris melalui perusahaan Zopa pada tahun 2005 yang kemudian diikuti di Amerika. Para pengguna pada awalnya tertarik dengan konsep peer to peer lending karena dampak krisis finansial 2008. Pada saat itu bank menutup penyaluran kredit baru dan memberikan suku bunga yang mendekati $0 \%$ kepada para deposan uang. Karena itu peminjam harus mencari sumber pendanaan alternatif dan pemilik dana aktif mencari investasi dengan imbal hasil yang lebih tinggi. ${ }^{1}$

Di Indonesia, sebelum Otoritas Jasa Keuangan (selanjutnya disebut OJK) menerbitkan Peraturan Otoritas Jasa Keuangan No. 77/POJK.01/2016 tentang Layanan Pinjam Meminjam Uang Berbasis Teknologi Informasi, platform peer to peer lending sejatinya telah ada dalam masyarakat. Sebagai contoh platform uangteman.com yang telah dikenal di Indonesia sejak 2015.

OJK menerbitkan POJK No. 77/POJK.01/2016 tentang Layanan Pinjam Meminjam Uang Berbasis Teknologi Informasi pada 28 Desember 2016.

${ }^{1}$ http://koinworks.com/id/education-center/industri-peer-to-peer-lending diakses pada tanggal 2 Mei 
Berdasarkan peraturan tersebut, yang dimaksud dengan layanan pinjam meminjam uang berbasis teknologi informasi adalah penyelenggaraan layanan jasa keuangan untuk mempertemukan pemberi pinjaman dengan penerima pinjaman dalam mata uang rupiah secara langsung melalui sistem elektronik dengan menggunakan jaringan internet. ${ }^{2}$

Peer to peer lending berbeda dengan layanan pinjam meminjam uang sebagaimana diatur pada Pasal 1754 KUHPerdata. Pada perjanjian pinjam meminjam uang sebagaimana diatur pada Pasal 1754 KUHPerdata para pihak yang terlibat adalah pemberi pinjaman dan penerima pinjaman dimana para pihak ini memiliki hubungan hukum secara langsung melalui perjanjian pinjam meminjam. Pemberi pinjaman berkewajiban untuk memberikan kepada pihak lain suatu jumlah tertentu barang yang menghabis karena pemakaian dengan syarat bahwa penerima pinjaman akan mengembalikan sejumlah yang sama dari macam dan keadaan yang sama pula. Sedangkan dalam layanan peer to peer lending, pemberi pinjaman tidak bertemu langsung dengan penerima pinjaman, bahkan diantara para pihak dapat saja tidak saling mengenal karena dalam sistem peer to peer lending terdapat pihak lain yakni platform peer to peer yang menghubungkan kepentingan antara para pihak ini.

Meskipun perusahaan penyelenggara platform peer to peer lending memiliki kemiripan dengan perbankan yang menerima uang dari deposan dan menyalurkannya melalui fasilitas kredit atau pembiayaan, perusahaan penyelenggara peer to peer lending bukanlah perbankan. Bank merupakan badan usaha yang menghimpun dana dari masyarakat dalam bentuk simpanan dan menyalurkannya kepada masyarakat dalam bentuk kredit dan/atau bentukbentuk lainnya dalam rangka meningkatkan taraf hidup rakyat banyak. ${ }^{3}$

Dalam sistem perbankan, hubungan hukum antara nasabah penyimpan dana dan bank didasarkan atas perjanjian antara nasabah penyimpan dana dan bank. Simpanan sendiri merupakan dana yang dipercayakan oleh masyarakat kepada bank berdasarkan perjanjian penyimpanan dana dalam bentuk giro, deposito

2 Pasal 1 angka 3 POJK No. 77/POJK.01/2016 tentang Layanan Pinjam Meminjam Uang Berbasis Teknologi Informasi

3 Pasal 1 angka 2 Undang-Undang Nomor 10 Tahun 1998 tentang Perubahan Atas Undang-Undang Nomor 7 Tahun 1992 tentang Perbankan. 
(berjangka), sertifikat deposito, tabungan dan/atau bentuk lainnya yang dipersamakan dengan itu. ${ }^{4}$ Lebih lanjut Undang-Undang No. 24 Tahun 2004 tentang Lembaga Penjamin Simpanan (LPS) menyatakan bahwa LPS berfungsi untuk menjamin simpanan nasabah dan turut serta secara aktif dalam memelihara sistem perbankan sesuai dengan kewenangannya. ${ }^{5}$

Mengingat perusahaan yang menjalankan platform peer to peer lending bukanlah perbankan sementara pinjaman melalui peer to peer lending mirip dengan kegiatan usaha perbankan, maka menarik untuk dikaji hubungan hukum antara pemberi pinjaman dengan perusahaan penyelenggara platform peer to peer lending yang tentu dalam hal ini ketentuan hukumnya berbeda dengan ketentuan hubungan hukum antara nasabah penyimpan dana dan perbankan. Kepastian hubungan hukum ini diperlukan agar kegiatan usaha peer to peer lending tidak terkategori sebagai bank gelap atau shadow banking.

Sebagai contoh platform peer to peer lending yaitu uangteman.com yang merupakan bagian dari PT. Digital Alpha Indonesia dan Digital Alpha Grup, Pte, Ltd, salah satu perusahaan digital keuangan di wilayah Asia Tenggara yang menyediakan pinjaman jangka pendek untuk keperluan konsumsi atau bisnis. ${ }^{6}$ Saat ini uangteman.com hanya menyediakan pinjaman untuk masyarakat Indonesia yang berada di daerah Jabodetabek, Yogyakarta, Solo, Magelang, Klaten, Bandung, Surabaya, Semarang, Bali, Makassar, Palembang, Lampung, Jambi, dan Balikpapan. ${ }^{7}$ Uangteman.com bertujuan untuk menyediakan pembiayaan online, sebagai alternatif dari model peminjaman konvensional bank atau perusahaan pembiayaan lainnya. ${ }^{8}$

Syarat untuk mengajukan peminjaman juga lumayan mudah. Calon nasabah harus Warga Negara Indonesia (WNI), berdomisili di Jabodetabek, Yogyakarta, Solo, Magelang, Klaten, Bandung, Surabaya, Semarang, Bali, Makassar, Palembang, Lampung, Jambi, dan Balikpapan, berusia 21 sampai dengan 65 tahun, memiliki penghasilan minimum Rp. 2.300.000,- untuk Jabodetabek, Bandung,

\footnotetext{
${ }^{4}$ Djoni S. Gazali dan Rachmadi Usman, Hukum Perbankan, Sinar Grafika, Jakarta, 2012, hlm. 242

${ }^{5}$ Jonker Sihombing, Penjaminan Simpanan Nasabah Perbankan, PT Alumni, Bandung, 2010, hlm. 58.

${ }^{6}$ https://uangteman.com/about, diakses pada tanggal 26 Mei 2017

${ }^{7}$ Ibid.

${ }^{8}$ Ibid.
} 
Surabaya, Bali dan Rp 2.000.000,- untuk Yogyakarta, Solo, Lampung, Jambi, dan Balikpapan, menyampaikan dokumen Kartu Tanda Penduduk (KTP), slip gaji atau bukti penghasilan dan foto pribadi, memiliki rekening tabungan atas nama nasabah, serta memiliki email sebelum mendaftar. ${ }^{9}$ Sistem pengembalian yang diberlakukan oleh UangTeman adalah sistem pembayaran satu kali, pada tanggal jatuh tempo nasabah diwajibkan untuk melunasi pokok pinjaman dan kewajiban biaya layanan yang dibebankan. Adapun besaran bunga yang harus dibayarkan oleh peminjam melalui layanan pinjaman online ini adalah sebesar $1 \%$ per hari. ${ }^{10}$ Bunga $1 \%$ per hari ini akan terus bertambah setiap harinya hingga maksimal jangka waktu pinjaman yakni 30 hari. Sistem ini dikenal dengan sistem compounding atau di masyarakat lebih dikenal dengan sistem bunga berbunga. Start up digital seperti "uangteman.com" sangat perlu untuk diawasi serta diatur dalam aturan yang berlaku di Indonesia. Uangteman.com berhubungan langsung dengan masyarakat yang tidak semua mengerti resiko yang bisa saja terjadi apabila meminjam uang melalui uangteman.com. Kebutuhan ekonomi yang mendesak bisa membuat seseorang tidak bijaksana dalam mengambil keputusan.

Berdasarkan hal-hal tersebut di atas, konstruksi hubungan hukum antara para pihak dalam peer to peer lending menjadi menarik untuk diteliti mengingat berdasarkan konstruksi hubungan hukum yang jelas akan memperjelas kedudukan hukum masing-masing pihak serta hak dan kewajiban masing-masing pihak dalam sistem peer to peer lending.

\section{Rumusan Masalah}

Bagaimana hubungan hukum antara para pihak dalam Peer To Peer Lending (Layanan Pinjam Meminjam Uang Berbasis Teknologi Informasi) ditinjau dari perspektif kepastian hukum bagi para pihak?

\section{Tujuan Penelitian}

Untuk mengkaji hubungan hukum antara para pihak dalam Peer To Peer Lending (Layanan Pinjam Meminjam Uang Berbasis Teknologi Informasi). Para pihak dalam peer to peer lending berbeda dengan para pihak dalam kegiatan usaha

${ }^{9}$ https://uangteman.com/work, diakses pada tanggal 26 Mei 2017

${ }^{10}$ Ibid. 
perbakan. Penyelenggara peer to peer lending bukanlah perbankan meskipun kegiatan usahanya mirip dengan perbankan. Oleh karena itu, memperjelas konstruksi hukum hubungan antara pihak diperlukan untuk menghindari adanya bank gelap atau shadow banking.

\section{Metode Penelitian}

Jenis penelitian ini merupakan penelitian hukum yuridis-normatif. Metode pengumpulan data dalam penelitian ini menggunakan studi pustaka dan dokumen atau arsip, yaitu dengan mengumpulkan data yang terkait dengan kebutuhan penelitian yang akan dikaji, selain itu berbagai buku dan bahan hukum pendukung lain juga dikumpulkan dan kemudian diverifikasi kesesuaiannya dengan kebutuhan penelitian. Penelitian ini mempergunkan metode analisis kualitatif, yakni data yang telah diperoleh akan diuraikan dalam bentuk keterangan dan penjelasan, selanjutnya akan dikaji berdasarkan pendapat para ahli, teori-teori hukum yang relevan, dan argumentasi peneliti sendiri.

\section{Hasil Penelitian dan Pembahasan}

Para Pihak yang Terlibat dalam Peer To Peer Lending (Layanan Pinjam Meminjam Uang Berbasis Teknologi Informasi)

Berbeda dengan perjanjian pinjam meminjam uang sebagaimana diatur pada Buku III KUHPerdata yang hanya melibatkan pihak pemberi pinjaman dan pihak penerima pinjaman, dalam peer to peer lending atau Layanan Pinjam Meminjam Uang Berbasis Teknologi Informasi melibatkan berbagai pihak yaitu:

\section{a. Penyelenggara Layanan Pinjam Meminjam Uang Berbasis Teknologi Informasi}

Pengertian penyelenggara layanan pinjam meminjam uang berbasis teknologi informasi telah diatur dalam Pasal 1 angka 6 POJK No. 77/POJK.01/2016 tentang Layanan Pinjam Meminjam Berbasis Teknologi Informasi. Penyelenggara dalam ketentuan tersebut adalah badan hukum Indonesia yang menyediakan, mengelola, dan mengoperasikan layanan pinjam meminjam uang berbasis teknologi informasi. Bentuk badan hukum penyelenggara dapat berupa perseroan terbatas 
atau koperasi. ${ }^{11}$ Berdasarkan ketentuan tersebut diatas, penyelenggara peer to peer lending haruslah badan hukum dan tidak dapat dilakukan oleh orang-perorangan maupun kegiatan usaha non badan hukum seperti Maatschap, Firma, ataupun CV. Badan hukum yang dapat bertindak sebagai penyelenggara peer to peer lending hanyalah perseroan terbatas yang telah mendapatkan pengesahan dari Kementerian Hukum dan HAM atau Koperasi. Ditinjau dari kapasitas hukum, tentu badan hukum memiliki kedudukan yang lebih baik jika dibandingkan dengan perusahaan non badan hukum mengingat badan hukum merupakan subjek hukum atau pendukung hak dan kewajiban yang dapat dimintai pertanggungjawaban atas nama badan hukum tersebut. Dengan ketentuan ini pula jelas bahwa Yayasan maupun badan hukum lainnya tidak dapat menjalankan kegiatan peer to peer lending. Persyaratan penyelenggara dalam bentuk badan hukum perseroan terbatas atau koperasi ini telah sesuai dengan tujuan kepastian hukum bagi para pihak dalam kegiatan usaha peer to peer lending dimana peer to peer lending merupakan kegiatan usaha yang bersifat mencari keuntungan (profit oriented) dan melibatkan banyak pihak.

\section{b. Pemberi Pinjaman}

Pemberi pinjaman sebagaimana diatur dalam Pasal 1 angka 8 POJK No. 77/POJK.01/2016 tentang Layanan Pinjam Meminjam Berbasis Teknologi Informasi adalah orang, badan hukum, dan/atau badan usaha yang mempunyai piutang karena perjanjian layanan pinjam meminjam uang berbasis teknologi informasi. Pemberi pinjaman dapat berasal dari dalam dan / atau luar negeri. Pemberi pinjaman terdiri dari orang perseorangan warga negara Indonesia, orang perserorangan warga negara asing, badan hukum Indonesia/asing, dan/atau lembaga internasional. ${ }^{12}$ Pemberi pinjaman dalam skema peer to peer lending lebih luas jika dibandingkan dengan penyelenggara peer to peer lending. Dalam hal ini, orang perorangan baik WNI maupun WNA dapat bertindak selaku pemberi pinjaman. Hal yang perlu diperhatikan agar kegiatan usaha peer to peer lending

11 Pasal 2 ayat (2) POJK No. 77/POJK.01/2016 tentang Layanan Pinjam Meminjam Berbasis Teknologi Informasi

12 Pasal 16 POJK No. 77/POJK.01/2016 tentang Layanan Pinjam Meminjam Berbasis Teknologi Informasi 
memberikan kepastian hukum bagi para pihak yaitu diperlukan pemberlakuan sistem "Know Your Customer" guna menghindari tindakan pencucian uang.

\section{c. Penerima Pinjaman}

Penerima pinjaman sebagaimana diatur dalam Pasal 1 angka 7 POJK No. 77/POJK.01/2016 tentang Layanan Pinjam Meminjam Berbasis Teknologi Informasi adalah orang dan/atau badan hukum yang mempunyai utang karena perjanjian layanan pinjam meminjam uang berbasis teknologi informasi. Penerima pinjaman dalam sistem peer to peer lending harus berasal dan berdomisili di wilayah hukum Negara Kesatuan Republik Indonesia. Penerima pinjaman dapat berupa orang perseorangan Warga Negara Indonesia atau badan hukum Indonesia. ${ }^{13}$ Berdasarkan ketentuan di atas, penerima pinjaman dalam peer to peer lending bukanlah perorangan WNA ataupun badan hukum asing. Namun, ketentuan tersebut belumlah cukup mengingat dalam ketentuan tersebut hanya disebutkan bahwa penerima pinjaman adalah pihak yang mempunyai utang tanpa menyebutkan dengan siapa penerima pinjaman mengikatkan diri dalam perjanjian utang-piutang atau pinjam meminjam. Hal ini seolah-olah penerima pinjaman memiliki perjanjian pinjam meminjam dengan penyelenggara peer to peer lending dimana hal tersebut mirip dengan kegiatan usaha perbankan dalam menerima dan menyalurkan dana ke masyarakat.

\section{d. Bank}

Pasal 24 POJK No. 77/POJK.01/2016 tentang Layanan Pinjam Meminjam Berbasis Teknologi Informasi menentukan bahwa penyelenggara wajib menggunakan escrow account dan virtual account dalam rangka layanan pinjam meminjam uang berbasis teknologi informasi. Selain itu, penyelenggara juga wajib menyediakan virtual account bagi setiap pemberi pinjaman dan dalam rangka pelunasan pinjaman, penerima pinjaman melakukan pembayaran melalui escrow account penyelenggara untuk diteruskan ke virtual account pemberi pinjaman.

Escrow Account adalah rekening yang dibuka secara khusus untuk tujuan tertentu guna menampung dana yang dipercayakan kepada Bank Indonesia

13 Pasal 15 POJK No. 77/POJK.01/2016 tentang Layanan Pinjam Meminjam Berbasis Teknologi 
berdasarkan persyaratan tertentu sesuai dengan perjanjian tertulis. ${ }^{14}$ Virtual Account adalah nomor identifikasi pelanggan perusahaan (end user) yang dibuat oleh Bank untuk selanjutnya diberikan oleh perusahaan kepada pelanggannya (perorangan maupun non perorangan) sebagai identifikasi penerimaan (collection). ${ }^{15}$

Tujuan penggunaan virtual account dan escrow account dalam hal ini yaitu larangan bagi penyelenggara dalam melakukan penghimpunan dana masyarakat melalui rekening penyelenggara. Guna mendukung penggunaan virtual account dan escrow account tersebut maka penyelenggara harus bekerjasama dengan pihak bank.

\section{e. Otoritas Jasa Keuangan (OJK)}

OJK adalah lembaga yang independen, yang mempunyai fungsi, tugas, dan wewenang pengaturan, pengawasan, pemeriksaan, dan penyidikan sebagaimana dimaksud dalam Undang-Undang No. 21 Tahun 2011 tentang Otoritas Jasa Keuangan. OJK dalam sistem pinjam meminjam uang berbasis teknologi informasi ini bertindak selaku pemberi persetujuan pengajuan pendaftaran dan perizinan penyelenggaraan sistem serta selaku pihak yang harus mendapatkan laporan berkala atas penyelenggaraan sistem pinjam meminjam uang berbasis teknologi informasi.

\section{Hubungan Hukum Antara Pemberi Pinjaman dan Penyelenggara}

Penyelenggara dalam laman peer to peer lending yang dikelolanya dapat menawarkan kepada masyarakat luas untuk berinvestasi dengan mengambil posisi sebagai pemberi pinjaman dalam peer to peer lending. Dalam hal ini, jika calon pemberi pinjaman tertarik untuk memberikan pinjaman melalui sistem peer to peer lending, maka pemberi pinjaman dan penyelenggara akan menyepakati perjanjian tertentu. Hubungan hukum antara pemberi pinjaman dan penyelenggara lahir atas adanya perjanjian yang dituangkan dalam dokumen elektronik diantara kedua

14 Penjelasan atas Peraturan Bank Indonesia No. 3/11/PBI/2001 tentang Perubahan Atas Perubahan Atas Peraturan Bank Indonesia No. 2/24/PBI/2000 tentang Hubungan Rekening Giro Antara Bank Indonesia dengan Pihak Ekstern

15 "Mandiri Virtual Account" http://www.bankmandiri.co.id/article/commercial-virtual-account.asp diakses pada tanggal 3 Agustus 2017 
belah pihak ${ }^{16}$. Dalam perjanjian ini harus ditentukan paling sedikit tentang nomor perjanjian,tanggal perjanjian, identitas para pihak, ketentuan mengenai hak dan kewajiban para pihak, jumlah pinjaman, suku bunga pinjaman, besarnya komisi, jangka waktu, rincian biaya terkait, ketentuan mengenai denda (jika ada), mekanisme penyelesaian sengketa, dan mekanisme penyelesaian dalam hal penyelenggara tidak dapat melanjutkan kegiatan operasionalnya. ${ }^{17}$

Dana yang dikelola oleh penyelenggara peer to peer lending yang diperoleh dari pemberi pinjaman akan disalurkan oleh penyelenggara kepada penerima pinjaman. Dalam hal ini, lantas bagaimanakah hubungan hukum antara para pihak? Tentu pertanyaan ini menarik untuk dikaji mengingat penyelenggara peer to peer lending bukanlah perbankan yang menjalankan fungsi intermediasi yaitu menghimpun dana dari masyarakat penyimpan dana dan menyalurkannya ke masyarakat melalui perjanjian kredit atau pembiayaan. Pelanggaran fungsi intermediasi ini dapat berujung pada penyelenggaraan bank gelap (shadow banking) yang dilarang di Indonesia sebagaimana diatur dalam UU Perbankan.

Pasal 46 ayat (1) dan (2) UU Perbankan menyatakan bahwa pihak yang menghimpun dana dari masyarakat dalam bentuk simpanan tanpa izin usaha dari Pimpinan Bank Indonesia dapat dikenakan pidana penjara paling lama 15 tahun serta denda sekurang-kurangnya Rp. 10.000.000.000,00 dan paling banyak Rp. 200. 000.000.000,00. Jika dilakukan oleh badan hukum yang berbentuk perseroan terbatas, perserikatan, yayasan atau koperasi, maka penuntutan terhadap badanbadan dimaksud dilakukan baik terhadap mereka yang memberi perintah melakukan perbuatan itu atau yang bertindak sebagai pimpinan dalam perbuatan itu atau terhadap kedua-duanya. Di sisi lain, berdasarkan Kitab Undang-Undang Hukum Pidana (KUHP), badan dan/atau pengurus badan tersebut dapat berpotensi dikenakan pasal perihal penggelapan (Pasal 372 KUHP) dengan ancaman sanksi pidana penjara paling lama empat tahun atau denda paling banyak Rp. 900.000 dan / atau penggelapan dalam jabatan (Pasal 374 KUHP) dengan Informasi

16 Pasal 19 ayat (1) POJK No. 77/POJK.01/2016 tentang Layanan Pinjam Meminjam Berbasis Teknologi

17 Pasal 19 ayat (2) POJK No. 77/POJK.01/2016 tentang Layanan Pinjam Meminjam Berbasis Teknologi Informasi 
ancaman pidana penjara paling lama lima tahun, dan/atau penipuan (Pasal 378 KUHP) dengan ancaman pidana penjara paling lama empat tahun. Ancaman tindak pidana penggelapan dan/atau penipuan bisa dijerat jika para penghimpun dana masyarakat ini sejak awal memiliki iktikad tidak baik yang mengakibatkan masyarakat mengalami kerugian. ${ }^{18}$

Guna menghindari pelanggaran tersebut di atas, konstruksi hukum hubungan hukum antara pemberi pinjaman dan penyelenggara dalam sistem peer to peer lending perlu dibedakan dengan konstruksi hubungan hukum antara nasabah penyimpan dana dengan bank. Dalam sistem perbankan, hubungan hukum antara nasabah penyimpan dana dan bank didasarkan atas perjanjian antara nasabah penyimpan dana dan bank. Simpanan sendiri merupakan dana yang dipercayakan oleh masyarakat kepada bank berdasarkan perjanjian penyimpanan dana dalam bentuk giro, deposito (berjangka), sertifikat deposito, tabungan dan/atau bentuk lainnya yang dipersamakan dengan itu. ${ }^{19}$

Apabila ditelusuri lebih lanjut bentuk-bentuk perjanjian bernama dalam Kitab Undang-Undang Hukum Perdata maka dijumpai beberapa perjanjian yang mendekati dengan fitur perjanjian penyimpanan (simpanan) dana bank ini. Disebutkan perjanjian penitipan (bewaargeving) sebagaimana dalam ketentuan Pasal 1694 KUHPerdata, bahwa penitipan adalah terjadi, apabila seorang menerima suatu barang dari seorang lain, dengan syarat bahwa ia akan menyimpannya dan mengembalikannya dalam ujud asalnya. Namun perjanjian penyimpanan dana di bank juga tidak sepenuhnya sama persis dengan lembaga penitipan, mengingat pada penyimpanan uang di bank maka uang tersebut akan digunakan oleh bank dalam menjalankan operasional kegiatan bank serta akan dikembalikan oleh bank kepada nasabah penyimpannya berikut dengan bunganya. Hal mana penggunaan barang titipan dilarang dalam KUHPerdata. Disisi lain, perjanjian penyimpanan dana juga identik dengan perjanjian pinjam meminjam uang sebagaimana diatur di KUHPerdata dimana bank selaku penerima pinjaman diperbolehkan menggunakan uang tersebut dan menyanggupi

18 "Praktik Bank Gelap" m.hukumonline.com/klinik/detail/lt5003cbf860b91/praktik-bank-gelap diakses pada tanggal 10 Juli 2017

19 Djoni S. Gazali dan Rachmadi Usman, Op. Cit. hlm. 242 
untuk membayar bunga. Pendapat lain menyatakan bahwa hubungan hukum antara bank dan nasabah didasarkan pada pemberian kuasa (lastgeving) sebagaimana diatur Pasal 1792 KUHPerdata. Dalam hal ini nasabah penyimpan dana memberikan kuasa kepada bank untuk memanfaatkan dana yang dipercayakan kepadanya dalam menjalankan kegiatan usaha perbankan. ${ }^{20}$ Namun Sutan Remy Sjahdeini tidak dapat menerima pendapat yang mengemukakan bahwa hubungan hukum antara bank dan nasabah penyimpan dana adalah hubungan pemberian kuasa. Hal tersebut salah satunya didasarkan pada apabila hubungan nasabah penyimpan dana dan bank adalah pemberian kuasa, maka bank sebagai penerima kuasa tentunya tidak dibenarkan untuk menggunakan uang nasabah bagi keperluannya, antara lain diberikan dalam bentuk kredit kepada pihak ketiga. ${ }^{21}$

Berdasarkan hal-hal tersebut di atas, hubungan hukum antara bank dan nasabah penyimpan dana tidak dapat dikategorikan ke dalam salah satu lembaga perjanjian yang ada di KUHPerdata, melainkan termasuk ke dalam hubungan hukum yang lahir dari perjanjian tidak bernama (innominaat contracten), artinya hubungan hukum antara bank dan nasabah penyimpan dana tidak dapat dikatakan sebagai perjanjian penitipan (uang), atau perjanjian pemberian kuasa, bahkan tidak dapat disebut sebagai perjanjian pinjam meminjam (uang). Dalam hal ini UU Perbankan telah mengkonstruksikan hubungan hukum antara bank dan nasabah penyimpan dana dengan bentuk perjanjian penyimpanan dana yang memiliki karakteristik tertentu. ${ }^{22}$

Adapun ciri-ciri perjanjian penyimpanan dana antara bank dan nasabah penyimpan dana yaitu pertama perjanjian simpanan bersifat riil, artinya lahirnya perjanjian tidak cukup diperlukan kesepakatan saja tetapi nasabah penyimpan harus menyerahkan uang kepada bank untuk disimpan. Kedua, uang yang telah diserahkan menjadi milik bank dan penggunaannya menjadi wewenang penuh bank. Ketiga, hubungan hukumnya adalah bank berkedudukan sebagai debitor dan nasabah penyimpan berkedudukan sebagai kreditor. Keempat, bank bukanlah

${ }^{20}$ Ibid., hlm. 245-249

${ }^{21}$ Ibid., hlm. 250

22 Ibid., hlm. 253 
sebagai peminjam uang dari nasabah penyimpan. Kelima, nasabah penyimpan bukan sebagai penitip uang pada bank. Keenam, bank akan mengembalikan simpanan nasabah dengan kontraprestasi berupa pemberian bunga. ${ }^{23}$

Mempertimbangkan hal-hal tersebut di atas, konstruksi hubungan hukum yang perlu ditegaskan antara pemberi pinjaman dan penyelenggara dalam sistem peer to peer landing yaitu uang yang diserahkan oleh pemberi pinjaman tidaklah ditujukan untuk dimiliki dan dikelola oleh penyelenggara seperti halnya dalam perjanjian pinjam meminjam uang melainkan hanya disalurkan saja oleh penyelenggara peer to peer lending kepada penerima pinjaman. Jika uang yang diserahkan oleh pemberi pinjaman masuk menjadi dana milik penyelenggara kemudian disalurkan oleh penyelenggara kepada peminjam, maka konstruksi ini tidak ubahnya dengan perjanijan penyimpanan dana dalam perbankan. Oleh karena itu, penggunaan escrow account dan virtual account mutlak diperlukan.

Hal yang harus dijaga dalam sistem peer to peer lending adalah harus adanya pemberian kuasa yang jelas dari pemberi pinjaman kepada penyelenggara untuk menyalurkan dana tersebut kepada penerima pinjaman. Dalam konsep ini, penyelenggara hanyalah menyediakan fasilitas yang mempertemukan pemberi pinjaman dan penerima pinjaman dan berdasarkan kuasa yang telah diberikan oleh pemberi pinjaman, penyelenggara untuk dan atas nama pemberi pinjaman menyepakati perjanjian pinjam meminjam uang milik pemberi pinjaman dengan penerima pinjaman. Untuk jasa yang telah dilakukan tersebut, penyelenggara peer to peer lending berhak mendapatkan fee atau upah. Berdasarkan uraian tersebut, maka konstruksi hubungan hukum antara pemberi pinjaman dan penyelenggara adalah hubungan hukum yang lahir dari perjanjian pemberian kuasa dengan pihak pemberi pinjaman selaku pemberi kuasa dan pihak penyelenggara selaku penerima kuasa.

Pemberian kuasa (lastgeving) diatur dalam Buku III Bab XVI mulai dari Pasal 1792 sampai dengan Pasal 1819 KUHPerdata. Pasal 1792 KUHPerdata menyatakan bahwa : 
"Pemberian kuasa adalah suatu perjanjian dengan mana seorang memberikan kekuasaan (wewenang) kepada seorang lain, yang menerimanya, untuk atas namanya menyelenggarakan suatu urusan."

Berdasarkan definisi mengenai pemberian kuasa tersebut, dapat ditarik kesimpulan bahwa surat kuasa (volmacht dalam bahasa Belanda atau Power of Attorney dalam bahasa Inggris) adalah surat yang berisi pemberian kuasa dari pemberi kuasa kepada penerima kuasa.

Dalam konsep pemberian kuasa, penerima kuasa memiliki beberapa kewajiban yaitu: ${ }^{24}$

a. Melaksanakan kuasa yang diberikan dengan sesempurna mungkin sesuai dengan wewenang/volmacht yang dilimpahkan oleh si pemberi kuasa. Pelaksanaan wewenang tadi harus diembannya dengan baik selama pemberian kuasa belum berakhir;

b. Wajib mempertanggungjawabkan kerugian yang timbul akibat kelalaian dan ketidaksempurnaan dalam melaksanakan wewenang yang dilimpahkan pemberi kuasa kepadanya;

c. Wajib melaporkan dan membuat perhitungan pertanggungjawaban atas segala sesuatu yang dilakukannya sehubungan dengan pelaksanaan tugas yang dilimpahkan kepadanya (Pasal 1802 KUHPerdata);

d. Wajib bertanggungjawab atas tindakan yang dilakukan oleh "kuasa substitusi" dan

e. Wajib membayar "bunga uang" tunai yang diterimanya jika uang yang diterimanya dipergunakan untuk kepentingan diri sendiri.

Sedangkan pemberi kuasa memiliki kewajiban yaitu: 25

a. Wajib mengganti segala uang panjar dan biaya-biaya yang telah dikeluarkan oleh si penerima kuasa dalam melaksanakan tugas yang dilimpahkan kepada si penerima kuasa; dan

b. Wajib membayar bunga atas pemakaian uang si penerima kuasa dalam melaksanakan tugas yang dibebankan kepada si penerima kuasa.

\section{Hubungan Hukum antara Pemberi Pinjaman dan Penerima Pinjaman}

Walaupun antara pemberi pinjaman dan penerima pinjaman dalam sistem peer to peer lending tidak saling bertemu secara langsung, hal mana disebabkan penerima pinjaman untuk mendapatkan pinjaman dimaksud cukup membuka aplikasi pinjaman online dan mengisi formulir pinjaman online, hubungan pinjam

\footnotetext{
${ }^{24}$ M. Yahya Harahap, Segi-Segi Hukum Perjanjian, Alumni, Bandung, 1986, hlm. 310

${ }^{25}$ Ibid., hlm. 311
} 
meminjam yang terjadi adalah antara pemberi pinjaman dan penerima pinjaman. Perjanjian pinjam meminjam tadi tidak terjadi antara penerima pinjaman dan penyelenggara. Hal ini harus dijaga agar konstruksi hubungan hukum antara para pihak dalam sistem peer to peer lending berbeda dengan konstruksi hubungan hukum antara para pihak dalam perbankan.

Dalam perbankan, bank menyalurkan dana kepada masyarakat melalui perjanjian kredit atau pembiayaan. Pengertian kredit sebagaimana diatur dalam Pasal 1 angka 11 UU Perbankan yaitu:

Kredit adalah penyediaan uang atau tagihan yang dapat dipersamakan dengan itu, berdasarkan persetujuan atau kesepakatan pinjam meminjam antara bank dengan pihak lain yang mewajibkan pihak peminjam untuk melunasi utangnya setelah jangka waktu tertentu dengan pemberian bunga.

Adapun pengertian pembiayaan sebagaimana diatur dalam Pasal 1 angka 12 UU Perbankan yaitu:

Pembiayaan berdasarkan Prinsip Syariah adalah penyediaan uang atau tagihan yang dipersamakan dengan itu berdasarkan persetujuan atau kesepakatan antara bank dengan pihak lain yang mewajibkan pihak yang dibiayai untuk mengembalikan uang atau tagihan tabungan setelah jangka waktu tertentu dengan imbalan atau bagi hasil.

Oleh karena itu, dalam sistem peer to peer lending, penyaluran pinjaman kepada penerima pinjaman haruslah bukan antara penyelenggara dan penerima pinjaman melainkan antara pemberi pinjaman dan penerima pinjaman. Untuk mewujudkan hal ini, pemberi pinjaman harus memberikan kuasa dengan tegas kepada penyelenggara untuk menyalurkan dananya kepada penerima pinjaman melalui escrow account dan virtual account. Penerima pinjaman yang akan melunasi pinjamannya dalam hal ini seharusnya dapat langsung membayarkannya melalui escrow account penyelenggara untuk diteruskan ke virtual account milik pemberi pinjaman mengingat hubungan hukum atas perjanjian pinjam meminjam terjadi antara pemberi pinjaman dan penerima pinjaman.

Pasal 1754 KUHPerdata menentukan bahwa pinjam meminjam adalah suatu perjanjian dengan mana pihak yang satu memberikan kepada pihak yang lain suatu jumlah tertentu barang-barang yang menghabis karena pemakaian, dengan syarat bahwa pihak yang terakhir ini akan mengembalikan sejumlah yang sama 
dari jenis dan mutu yang sama pula. Dalam istilah "verbruik-lening" yaitu nama dalam bahasa Belanda untuk perjanjian pinjam meminjam ini, perkataan "verbruik" berasal dari "verbruiken" yang berarti menghabiskan. ${ }^{26}$

Adapun kewajiban pemberi pinjaman yaitu tidak boleh meminta kembali apa yang telah dipinjamkannya sebelum lewatnya waktu yang ditentukan dalam perjanjian (Pasal 1759 KUHPerdata). Selain itu jika tidak telah ditetapkan suatu waktu, hakim berkuasa, apabila orang yang meminjamkan menuntut pengembalian pinjamannya, menurut keadaan, memberikan sekedar kelonggaran kepada si peminjam (Pasal 1760 KUHPerdata).

Kewajiban penerima pinjaman yaitu wajib mengembalikan barang dalam jumlah dan keadaan yang sama dan pada waktu yang ditentukan (Pasal 1763 KUHPerdata). Kewajiban lain dari si penerima pinjaman yaitu jika penerima pinjaman tidak mampu mengembalikan barang yang dipinjamnya dalam jumlah dan keadaan yang sama, maka ia diwajibkan membayar harganya, dalam hal mana harus diperhatikan waktu dan tempat dimana barangnya, menurut perjanjian, harus dikembalikan. Jika waktu dan tempat ini tidak telah ditetapkan, harus diambil harga barang pada waktu dan tempat dimana perjanjian telah terjadi (Pasal 1764 KUHPerdata); dan jika telah diperjanjikan bunga, maka bunga yang telah diperjanjikan tersebut harus dibayar sampai saat pengembalian atau penitipan uang pokoknya (Pasal 1766 KUHPerdata).

\section{Hubungan Hukum antara Penyelenggara dan Bank}

Hubungan hukum antara penyelenggara dan bank lahir atas adanya perjanjian penggunaan virtual account dan escrow account sebagaimana diamanatkan Pasal 24 POJK No. 77/POJK.01/2016 tentang Layanan Pinjam Meminjam Berbasis Teknologi Informasi. Diharapkan dengan skema online ini, yakni pengiriman informasi tagihan (collection) dapat secara online, penyediaan informasi status pinjaman kepada para pihak juga secara online, dan penyediaan

${ }^{26}$ R. Subekti, Aneka Perjanjian, PT Citra Aditya Bakti, Bandung, 1995, hlm. 126 
escrow account dan virtual account di perbankan kepada para pihak sehingga seluruh pelaksanaan pembayaran dana berlangsung dalam sistem perbankan. ${ }^{27}$

Ketentuan tersebut di atas memberikan kemudahan sekaligus kepastian hukum bagi para pihak yaitu antara penyelenggara peer to peer lending dan bank. Pelibatan pihak bank dalam skema peer to peer lending sebagai pihak penyedia virtual account dan escrow account ini menunjukkan bahwa sistem pembukuan yang harus dijalankan oleh penyelenggara peer to peer lending harus berjalan seefisien mungkin dan tetap dapat dipertanggungjawabkan.

\section{Hubungan Hukum antara Penyelenggara dan OJK}

Hubungan hukum antara penyelenggara dan OJK lahir atas dasar ketentuan peraturan perundang-undangan dalam hal ini POJK No. 77/POJK.01/2016 tentang Layanan Pinjam Meminjam Berbasis Teknologi Informasi. Berdasarkan ketentuan POJK ini, penyelenggara yang bermaksud menjalankan penyelenggaraan sistem peer to peer harus mendapatkan izin dari OJK ${ }^{28}$ dan setelah menjalankan sistem peer to peer lending harus memberikan laporan berkala ke OJK. ${ }^{29}$ Berdasarkan ketentuan tersebut, jelas penyelenggaraan peer to peer lending harus seizin dan dibawah pengawasan OJK. Hubungan hukum antara penyelenggara peer to peer lending dan OJK adalah hubungan hukum yang lahir dari ketentuan peraturan perundangundangan bukan atas dasar perjanjian. OJK sebagai lembaga independen yang dibentuk berdasar undang-undang memiliki kapasitas sebagai pengawas kegiatan usaha yang dijalankan oleh Lembaga Jasa Keuangan (LJK). Hal ini ditujukan untuk mewujudkan kepastian hukum dan perlindungan hukum bagi para pihak.

\section{Penutup}

Berdasarkan analisis yang telah diuraikan pada bagian sebelumnya, dapat diambil kesimpulan yaitu hubungan hukum antara para pihak dalam peer to peer lending (layanan Pinjam Meminjam Uang Berbasis Teknologi Informasi) haruslah dibedakan dengan hubungan hukum antara para pihak dalam sistem perbankan

27 "16 Hal yang Wajib Dipenuhi Pemain Peer to Peer Lending dalam Fintech" http://m.hukumonline.com/index.php/berita/baca/lt586e1f6a2e0a2/16-hal-yang-wajib-dipenuhi-pemain-peerto-peer-lending-dalam-fintech diakses pada tanggal 6 Agustus 2017

${ }^{28}$ Pasal 7 POJK No. 77/POJK.01/2016 tentang Layanan Pinjam Meminjam Berbasis Teknologi Informasi

29 Pasal 9 POJK No. 77/POJK.01/2016 tentang Layanan Pinjam Meminjam Berbasis Teknologi Informasi 
agar tidak melanggar ketentuan perizinan usaha di bidang perbankan yang dapat berimplikasi pada penyelenggaraan bank gelap (shadow banking). Oleh karena itu, hubungan antara pemberi pinjaman dan penyelenggara peer to peer lending haruslah bukan hubungan penyimpanan dana melainkan hubungan hukum yang lahir atas perjanjian pemberian kuasa. Di sisi lain, penerima pinjaman dalam peer to peer lending secara yuridis seharusnya memiliki hubungan hukum dengan pemberi pinjaman dan bukan dengan penyelenggara peer to peer lending. Hubungan hukum antara penerima pinjaman dan pemberi pinjaman dalam hal ini merupakan hubungan pinjam meminjam uang sebagaimana diatur pada KUHPerdata. Adapun keberadaan penyelenggara peer to peer lending adalah sebagai kuasa dari pemberi pinjaman guna bertindak untuk dan atas nama pemberi pinjaman mengadakan perjanjian pinjam meminjam uang dengan penerima pinjaman.

Oleh karena itu, Otoritas Jasa Keuangan perlu segera menerbitkan peraturan yang lebih jelas berkaitan dengan konstruksi hubungan hukum para pihak dalam sistem peer to peer lending. Mengingat konstruksi hubungan hukum yang jelas tersebut akan mempermudah pelaksanaan hak dan kewajiban masing-masing pihak yang terlibat dalam sistem peer to peer lending. Kepastian hubungan hukum antara para pihak dalam peer to peer lending juga akan memberikan kedudukan hukum yang sah bagi penyelenggara peer to peer lending.

\section{Daftar Pustaka}

\section{Buku}

Gazali, Djoni S. dan Rachmadi Usman, Hukum Perbankan, Sinar Grafika, Jakarta, 2012.

Harahap, M. Yahya, Segi-Segi Hukum Perjanjian, Alumni, Bandung, 1986.

R. Subekti, Aneka Perjanjian, PT Citra Aditya Bakti, Bandung, 1995.

Sihombing, Jonker, Penjaminan Simpanan Nasabah Perbankan, PT Alumni, Bandung, 2010.

\section{Jurnal}

Afaf, Azizah et.al, "Perlindungan Hukum Bagi Pemberi Pinjaman Terhadap Risiko Gagal Bayar Dalam Perjanjian Peer To Peer Lending" Jurnal Hukum http://hukum.studentjournal.ub.ac.id., 2017. 


\section{Peraturan Perundang-Undangan}

Kitab Undang-Undang Hukum Perdata

Undang-Undang Republik Indonesia Nomor 21 Tahun 2011 tentang Otoritas Jasa Keuangan (Tambahan Lembaran Negara Republik Indonesia Nomor 5253)

Undang-Undang Nomor 10 Tahun 1998 tentang Perubahan Atas Undang-Undang Nomor 7 Tahun 1992 tentang Perbankan (Tambahan Lembaran Negara Republik Indonesia Nomor 3790)

Peraturan Otoritas Jasa Keuangan No. 77/POJK.01/2016 tentang Layanan Pinjam Meminjam Uang Berbasis Teknologi Informasi (Lembaran Negara Republik Indonesia Tahun 2016 Nomor 324)

Peraturan Bank Indonesia No. 3/11/PBI/2001 tentang Perubahan Atas Perubahan Atas Peraturan Bank Indonesia No. 2/24/PBI/2000 tentang Hubungan Rekening Giro Antara Bank Indonesia dengan Pihak Ekstern (Tambahan Lembaran Negara Republik Indonesia Nomor 4108)

\section{Internet}

"Mandiri Virtual Account" http://www.bankmandiri.co.id/article/commercialvirtual-account.asp diakses pada tanggal 3 Agustus 2017

"Praktik Bank Gelap" m.hukumonline.com/klinik/detail/lt5003cbf860b91/ praktik-bank-gelap diakses pada tanggal 10 Juli 2017

"16 Hal yang Wajib Dipenuhi Pemain Peer to Peer Lending dalam Fintech" http:/ / m.hukumonline.com/index.php/berita/baca/lt586e1f6a2e0a2/16hal-yang-wajib-dipenuhi-pemain-peer-to-peer-lending-dalam-fintech diakses pada tanggal 6 Agustus 2017

https:/ / uangteman.com/work, diakses pada tanggal 26 Mei 2017

http:/ / koinworks.com/id/education-center/industri-peer-to-peer-lending diakses pada tanggal 2 Mei 2017 